\title{
Unpackaging the Psychology of Immigration
}

\author{
Rodney Blackman ${ }^{1 *}$ and Wanyi Tang ${ }^{2}$ \\ ${ }^{1}$ Chair of Recreation Management, United States Sports Academy, USA \\ ${ }^{2}$ Teaching Assistant and Doctoral Student, United States Sports Academy, USA
}

Submission: April 04, 2018; Published: April 17, 2018

*Corresponding author: Rodney Blackman, Chair of Recreation Management; United States Sports Academy, Daphne, Alabama, USA; Email: rblackman@ussa.edu

\section{Abstract}

Increasingly, over the past decade immigration policies and reforms have emerged as provocative assembly kits for politically infused rhetoric. Because of this rhetoric, or perhaps in spite of it, what have also emerged are viable concerns for the global citizenry. Several overlapping issues have developed, especially in matters associated with the intersection between immigration and sports, recreation, leisure services, and tourism. This qualitative document analysis study included an overview of salient issues relevant to the varied convergences between these high-visibility phenomena.

For the purpose of identifying specific areas of future research, this study was phenomenological. The 2009 report conducted by the World Tourism Organization (WTO) was used as a baseline and reference point for this study. Additional associated reports, newspaper publications, popular literature, web-based publications, empirically based research articles, blogs, and public commentaries were examined for the collection of information addressing matters relevant to immigration and the intersections of such matters with sports, recreation, tourism, and leisure services. Data from varied sources were examined in light of patterns that emerged from within these intersections. Along with an overview of the context provided in the 2009 report, these patterns and their associated impacts were identified, clarified, and highlighted and is presented in the following paragraphs. In addition, suggested areas for future research are also presented.

\section{Introduction}

The main transactions of tourism and migration occur between the origin market and the destination market. Accordingly, several interfaces emerged in the 2009 report, including human migration, migrant skills and human capital, and the benefits of immigration. Associated trends suggest that 1) immigration can lead to social problems in the destination countries, 2) migrant workers are often employed in sports, recreation, leisure services, travel, tourism, and hospitality sectors, and 3) immigration contributes to the development of new cultural products, enriching the cosmopolitan environment of destination countries World Tourism Organization [1].

\section{Definitions of Status}

Migrant laborers are considered regular and temporary labor migrants, or guest workers (also known as overseas contract workers other than highly skilled or business migrants). These include people who migrate for a limited time in order to complete employment projects, to save or send money home. The temporary status of these migrants indicates that over time they may become return migrants, also known as circular migrants World Tourism Organization [1]. Irregular migrants or undocumented/illegal migrants are people who enter a country to search for employment, and without the necessary documents and permits. These migrants typically have lower negotiating power and may experience social exclusion. If employed in the sports, recreation, tourism, or leisure services industry, they may lower the quality of services offered and/or negatively affect the tourism destination image and marketability World Tourism Organization [1].

Highly skilled and business migrants are people with qualifications as managers, executives, professionals, technicians, who move within the labor markets of transnational corporations and international organizations, or who seek employment through international labor markets. Many countries welcome these migrants and offer programs to inveigle them to come World Tourism Organization [1]. Family migrants are people who share family ties joining with other people who have already entered an immigration country among one of the previously mentioned categories. Some countries allow this, while others do not. Return migrants are people who return to their countries of origin after a period of time in another country (World Tourism Organization [1].

Resident migrants are people who hold a second residence, which may eventually become their primary residence, in another country, and to which they can travel freely, and 
where they can live on income earned in their country of origin. Refugees are people who have been forcefully displaced from their home country and made to escape by dangers of war, violence, disaster, or persecution in their home country World Tourism Organization [1]. Another popular term associated with immigration is assimilation. One definition is that assimilation refers to integration - the process by which the characteristics of members of immigrant groups and host societies come to resemble one another Brown [2]. Increasingly, and comprehensively, for the most harmonious immigration to occur, assimilation must occur as seamlessly and as pervasively as possible.

The pockets or cells of non-assimilated migrants often facilitate the fostering of additional dangers. Unfortunately, there are substantial challenges that accompany this process. According to Angela Merkel, Chancellor of Germany, cooperation and not isolation will best shape the healthiest of respectful foreign policies, including immigration policies. Not surprisingly, there is quite often a disparity between official migrant policies and how migrants, in reality, are treated. For example, how skilled migrant laborers are handled varies greatly according to cultural differences between destination markets Parker [3].

\section{Cultural Trends}

Notably, skilled migrant labor in similar geographic regions such as Japan, Sri Lanka, Bangladesh, India, the Philippines and China, for example, are coveted, and treated with measured favoritism Lan [4]; Smith [5]. However, treatment of those from both skilled and unskilled migrant labor sectors in Brazil, Russia, Qatar and some other countries-such treatment has come under heavy criticism, for the alleged inhumane treatment of the migrant laborers Foster [6]; Lally [7]; Liew [8]; Salles [9]; Smith [10]. Reports have surfaced of migrants having their passports confiscated, not being paid, forced to work 16 to 20-hour days in extreme heat, meager rations, slum-like living conditions, overcrowding, open-air sewage pits, and rampant disease. According to numerous reports, migrant worker death rates have soared, and in some places, it has been discovered that health care services have not been provided because it is cheaper to replace dead workers than it is to provide health care for injured or ill ones.

Summarily, managers of migrant workers have routinely abused the inherent power differential that is present between indigenous work managers and migrant workers. Interestingly, many of these atrocities being visited upon migrant laborers have come while said laborers were working on the construction of sports stadiums for the Olympics or the FIFA World Cup. In the United States (US) and Canada, there have been differing perspectives on immigration. Where the US was once a melting pot, with beliefs, values, lives and differences being appreciated and fluidly blended, it has come, of late, to more closely resemble a salad bowl. Isolationism has become the norm, and separate parts are tossed about - for the separating out of individual parts. This is inconsistent with the appreciation and blending of differences, but rather, is aligned with isolation and highlighting of said differences Fotopoulos [11]; Krogstad [12].

The Canadian perspective, as characterized by Justin Trudeau, the Prime Minister of Canada, is closely aligned with the notions of cooperation and collaboration. Trudeau encouraged the embrace of both the excitement and challenge of advances in technology. While the gap between the haves and the have nots is increasingly widening, Trudeau contends that cooperative effort, spearheaded by issues such as migrant and host assimilation is the real root of societal progress - and, such progress will inevitably translate into economic growth, despite a myriad of outside influences Trudeau 2018. In Europe, several confounding factors seem to be at work, from Brexit, to substantially sized migrant communities, to multiple terrorist cells and terrorist attacks known to be associated with immigrants. Members of indigenous communities have been killed, and therefore social consciousness has been electrified. While individual countries within the European community search to find what's right for them, individually, social awareness has become piqued. In addition, the nature and the timing of terrorist attacks have injected an extra measure of fear and anxiety into the hearts of the European constituency. Still, remarkably, there is a strong push for global cooperation, especially in terms of immigration Fotopoulos [11]; Parker [3]. In many respects, Ireland, for example, has become the new melting pot. Past efforts at "making Ireland Irish" have been that Irish hosts, more accustomed to seeing people leave their country than move in, have put on a bit for the sake of tourists. Now, the Irish are recipients of grafting onof immigrant populations. To aid in assimilation, the Irish put the immigrants to work Zuelow [13]. Their attitude may best be characterized by the chorus lyrics from the popular Irish song, "Walk beside me"...

\section{"Don't walk in front of me \\ I was not born to follow \\ Don't walk behind me}

We were all born to lead

Don't walk without me

I might need you tomorrow

Walk right beside me

Be the real friend I need" Lang \& Nilsson [14].

\section{Economic Influences}

Merkel declared that data will be the raw material of the $21^{\text {st }}$ Century Parker [3]. This very well may become true, but most certainly, as is already bearing out, creativity is as important as literacy Robinson, as cited in King [15], and artificial intelligence (AI) will totally revolutionize the world of work. It is staggering 
to consider that, as fast as it is, the pace of change in the world will never be this slow again. The impact of this on both tourism and migration will be exponential, as early as within the next five years Parker [3]; Trudeau 2018. Accordingly, one might expect that it will be increasingly difficult for immigrants to be successful in their host country environments. In particular, Bustamente [16] observed that migrants are inherently vulnerable due to the fact that they selected to leave their most stable position, their homes, in order to become migrants. Consequently, when political, economic, or social turmoil occurs, migrants are more likely to be exposed to higher risks. Accordingly, immigrants may have to work harder by far than everyone else - just to be able to keep up; and they are already situational compromised. Keeping up will require full commitment, or an exceedingly generous set of circumstances. In fact, immigrants have already begun to be, and will continue to be viewed as capital, or humans as resources. In particular, there has begun a race, or what may even be characterized as a war for skilled immigrant labor. But that is only one side of the story- the other side is far more ominous. Human trafficking has become one of the fastest growing commercial enterprises across the globe. While to some this is unfathomable or unforgivable, to others it is a natural offspring of immigration Malloy [17].

And estimated 36 million people are held in slavery every day. Children represent $26 \%$ of forced labor victims. Supply and demand and relatively low risks of being caught have driven the popularity of human trafficking to never-before-seen levels. Accordingly, it has become well established that human trafficking is fueled, at least in part, by immigration Malloy [17]. Interestingly, immigration is a natural human phenomenon just as much as any other human phenomenon is a human phenomenon. Travel for the sake of tourism may be closely aligned with the more sophisticated or prosperous civilizations, yet immigration is human to every civilization. Accordingly, as long as there is inequality, there will be immigration. Just the same as it is that humans have a survival instinct, there is also a tendency to seek to make one's life better, particularly if and when stability, one's life, and/or well-being are threatened. Similarly, some immigration scenarios may properly be classified as chronic; still, leaders and administration tasked with the management of those situations must do their due diligence to achieve goals for the common good of all parties affected and uncover best-practice solutions for immigration policy and reform [18].

\section{Future Research}

With all the potential for great human benefit that can be associated with the power of sports, recreation, leisure services, and tourism, it is not surprising that there are also some very powerful forces originating from the underbelly of humankind. Future research in this area could greatly benefit our understanding of how to fully un-package the psychological issues associated with immigration. The recommended areas of focus for future research should include and examination of socialization and integration under stress. In addition, whereas fear and anxiety may shorten the stay of immigrants in destination countries, future examination of immigrant length of stay cycles and patterns may inform how immigrant length of stay will impact policy implications, reform, and implementation.

\section{References}

1. World Tourism Organization (2009) Tourism and migration-Exploring the relationship between two global phenomena. Madrid, Spain.

2. Brown SK, Bean FD (2006) Assimilation models, old and new: Explaining a long-term process. Migration policy institute, Washington, USA.

3. Parker C (2018) Angela Merkel at Davos: We need global cooperation, not walls. World Economic Forum.

4. Lan S (2014) State regulation of undocumented African migrants in China: A multi-scalar analysis. Journal of Asian and African studies 50(3): 289-304.

5. Smith N (2017) Japan struggles to attract immigrants as shrinking population time bomb keeps on ticking independent.

6. Foster A (2017) Death toll rises in the lead up to the 2022 world cup. News.com.au.

7. Lally K (2013) Olympic construction besets Russia's Sochi. Washington post.

8. Liew J (2017) World Cup 2022: Qatar's workers are not workers, they are slaves, and they are building mausoleums, not stadiums. Independent.

9. Salles JM (2016) Don't forget the construction workers who died making the Rio Olympics happen. Think progress.

10. Smith G (2016) Another report damns Qatar's treatment of world cup workers.

11. Fotopoulos $T$ (2017) The crisis of the ideology of neoliberal globalization. The international journal of inclusive democracy 13: 1-2.

12. Krogstad JM, Gonzalez-Barrera A (2018) Key facts about US immigration policies and proposed changes. Fact Tank-News in the numbers.

13. Zuelow E (2009) Making Ireland Irish: Tourism and national identity since the Irish civil war. Syracuse University Press, Syracuse, New York, USA.

14. Lang RJ, Nilsson TB (2015) Walk Beside Me. On the Celtic Woman Destiny CD. Manhattan Records. Los Angeles, California, USA.

15. King MJ (2018) Why we feel, think, decide, and buy. Cultural Intelligence blog. Center for cultural studies and analysis.

16. Bustamante JA (2011) Extreme vulnerability of migrants: The cases of the United States and Mexico. Migracionesinternacionales 6(1).

17. Malloy B (2016) The economics of human trafficking. Institute for faith, work \& economics.

18. Conn D (2017) Thousands of Qatar World Cup workers subjected to life-threatening heat. 
This work is licensed under Creative Commons Attribution 4.0 License

DOI: 10.19080/PBSIJ.2018.09.555751

\section{Your next submission with Juniper Publishers} will reach you the below assets

- Quality Editorial service

- Swift Peer Review

- Reprints availability

- E-prints Service

- Manuscript Podcast for convenient understanding

- Global attainment for your research

- Manuscript accessibility in different formats ( Pdf, E-pub, Full Text, Audio)

- Unceasing customer service

Track the below URL for one-step submission https://juniperpublishers.com/online-submission.php 